\title{
Fruiting of "Keitte" Mango Trees in Relation to Application of Glutathione and Boron
}

\author{
Amr M. E. Haikal ${ }^{1}$ and Alaa M. Gomaa ${ }^{2}$ \\ ${ }^{1}$ Department of Horticulture, Faculty of Agriculture, Suez Canal University, Ismailia - 41522, Egypt \\ ${ }^{2}$ Department of Horticulture, Faculty of Agriculture, Damanhour University, El-Beheira, Egypt
}

Received: $21 / 6 / 2017$

\begin{abstract}
This study was conducted during 2014 and 2015 seasons to examine the effect of spraying boric acid and/or glutathione each at $(0.05$ up to $0.1 \%)$ three times at monthly intervals starting from the first March, on growth, tree nutritional status, yield and fruit quality of "Keitte" mango trees grown under sandy calcareous soil. An obvious promotion was revealed on all growth aspects, leaves pigments and nutrients content, fruit retention\%, yield and fruit quality as affected by the tested treatments. Glutathione was appreciably superior to boric acid in this respect and using both together was preferable than using them individually. The promising treatment was the application of boric acid plus the antioxidant glutathione each at 0.1 and $0.05 \%$ without significant differences among them. Therefore, from the economical point of view, it is advised to use this treatment at $0.05 \%$, to obtain acceptable yield and fruit quality of "Keitte" mango trees grown under sandy calcareous soil.
\end{abstract}

Keywords: "Keitte" mango, glutathione, boron, yield, fruit quality

\section{INTRODUCTION}

Yield decline of "Keitte" mango trees grown under sandy saline and calcareous soil could be cured by using non-conventional practical methods such as using glutathione and boron that are famous for their promising effect on nutrition of different fruit crop species.

Glutathione as an important antioxidant is the most essential non-protein thiol present in the plants. It is essential in sulphur assimilation, nutrition and metabolism and defense against most biotic and abiotic stresses. It consists of three amino acids namely cysteine, glutamic and glycine. It is important pool of reduced sulphur and it regulates uptake of $\mathrm{S}$. It is responsible for preventing the great damage caused by free radicals through react directly or indirectly with reactive oxygen species (ROS) and maintain the integrity of cell structure and the proper functions of various metabolic pathways. It is responsible for the expression of defense genes and involved in redox control of cell division. It is very potent in enhancing the biosynthesis of amino acids and proteins and it is associated with mechanisms of acclamation and adaptation (Rennenberg, 1982; Meister and Anderson, 1983; Jorge et al., 1993; Dekok and Stulen, 1993; Noctor and Foyer, 1998; Kocsy et al., 2001; Mengel et al., 2011; Grill et al., 2001).

Foyer and Lelandias (1993), Mullelineaux and Rausch (2005), Khattab (2007) and Szala et al. (2008) emphasized the beneficial of glutathione on enhancing the tolerance of plants to all stresses.

Boron is essential micronutrients for all fruit crop species development. It is very important for all reproductive tissues. During flowering and fruit setting, boron deficiency can result in dropping of flowers and poor fruit setting, since it plays a main role in early seasons shoot growth; pollen growth and tube germination, since it is needed for fertilization process and fruit setting (Mengel et al., 2001; Peacock and Christensen, 2005; Marschner, 2012).

For all the previous great functions of both the antioxidant glutathione and boron the idea of using both on promoting the productions of "Keitte" mango trees was bursted.

Previous studies showed that using glutathione (Mahgoub-Mona et al., 2006; El-Khawaga et al., 2007; Mohamed, 2012; Abdelaal et al., 2012; Gad ElKareem, 2012; Ahmed et al., 2012; Al-Qubaie, 2012; El-Khawaga and Mansour, 2014; Gaber, 2016) and boron (Abo El-Komsan et al., 2003; Abd-Allah, 2006; El-Sayed-Esraa, 2007; Ebeid-Sanaa, 2007; Desouky et al., 2007; Abdalla, 2008; Ahmed et al., 2009; Harhash and Abdel-Nasser, 2010; Gamal, 2013; Hassan-Huda, 2014; Ibrahim and Al-Wasfy, 2014; Mahmoud, 2015; Abd El-Wahab, 2015; Mohamed et al., 2015; Abdelbaky, 2015; Mostafa, 2015; Habasy-Randa et al., 2016; Mahmoud, 2016) was very effective in improving yield and fruit quality in different horticultural crop species.

The target of this study was to examining the effect of spraying glutathione and/or boron on growth, yield and fruit quality of "Keitte" mango trees.

\section{MATERIALS AND METHODS}

This experiment was conducted during 2014 and 2015 seasons on 30 "Keitte" mango cv. trees onto Succary mango rootstock, grown in sandy calcareous soil in a private mango orchard situated at Delengat district, Beheara Governorate, Egypt. The selected trees were 7-years old, healthy, nearly uniform in vigour, planted at 2 (between trees) x3 (between rows) meters apart and received the same horticultural practices that already applied in the orchard. Drip irrigation system using well saline irrigation water containing $350 \mathrm{ppm}$ saline was used. Soil analysis was done according to the procedure that outlined by Chapman and Pratt, (1965) and the data are shown in Table (1). 
Table (1): Analysis of the tested soil

\begin{tabular}{lc}
\hline Content & Value \\
\hline Sand \% & 78.2 \\
Silt \% & 6.8 \\
Clay\% & 15.0 \\
Texture & Sandy \\
O.M. \% & 0.52 \\
pH (1: 2.5 extract) & 8.0 \\
EC (1: 2.5 extract) dsm ${ }^{-1}$ ) & 1.0 \\
Calcium carbonate \% & 7.1 \\
Total N\% & 0.03 \\
Available P (Olsen, ppm) & 1.8 \\
Available K (ammonium \\
acetate, ppm) \\
EDTA extractable
\end{tabular}

This experiment included the following ten treatments:

1. Control (sprayed with water).

2. Spraying boric acid at $0.025 \%(0.25 \mathrm{~g} / \mathrm{L})$.

3. Spraying boric acid at $0.05 \%(0.5 \mathrm{~g} / \mathrm{L})$.

4. Spraying boric acid at $0.1 \%(1.0 \mathrm{~g} / \mathrm{L})$.

5. Spraying glutathione at $0.025 \%(0.25 \mathrm{~g} / \mathrm{L})$.

6. Spraying glutathione at $0.05 \%(0.5 \mathrm{~g} / \mathrm{L})$.

7. Spraying glutathione at $0.1 \%(1.0 \mathrm{~g} / \mathrm{L})$.

8. Spraying boric acid and glutathione each at $0.025 \%$.

9. Spraying boric acid and glutathione each at $0.05 \%$.

10. Spraying boric acid and glutathione each at $0.1 \%$.

Each treatment was replicated three times, one tree per each. Therefore, for carrying out this study, thirty uniforms in vigor "Keitte" mango trees were selected. Boric acid $(17 \%$ B) and the antioxidant glutathione were sprayed three times at the first week of March, April and May during both seasons. Triton B as a wetting agent was added to all solutions at $0.05 \%$ and spraying was done till runoff (10-20 L/tree according to the date of spraying). Randomized complete block design (RCBD) was followed.

During both seasons, the following parameters were measured, main shoot length $(\mathrm{cm}$.) and leaf area $(\mathrm{cm})^{2}$ of non-fruiting shoots (5 - 6 months old) (Ahmed and Morsy, 1999); leaf pigments namely chlorophylls a and $\mathrm{b}$, total chlorophylls and total carotenoids mg/100gF.W; (von-Wettstine, 1957); of Npercentages, $\mathrm{P}, \mathrm{K}, \mathrm{Mg}, \mathrm{Ca}$ and $\mathrm{S}$ (on dry weight basis) in the leaves taken from non-fruiting shoots of (5-6 months old) (Summer, 1985 and Carter, 1993); fruit retention \%; yield expressed in weight (kg.) and number of fruits/tree. In addition, physical and chemical characteristics of fruits were estimated. weight (g.), height, diameter and thickness $(\mathrm{cm})$, percentages of seeds, peels and pulp of the fruit, edible (pulp) to nonedible (seeds and peels) portions of the fruit, percentages of T.S.S., total acidity as $\mathrm{g}$ citric acid $/ 100 \mathrm{~g}$ pulp, total and reducing sugars, vitamin $\mathrm{C}$ content (mg/100 g pulp) and total fibre \% (A.O.A.C, 2000) were evaluated.

Statistical analysis was done according to Snedecor and Cochman (1980) and New L.S.D. test at $5 \%$ was used to differentiate among the various treatment means.

\section{RESULTS}

\section{Growth aspects}

Data in Table (2) revealed that single and combined applications of both boric acid and glutathione each at 0.025 up to $0.1 \%$ had significant stimulation on shoot length and leaf area of "Keitte" mango trees relative to the control treatment. The promotion was related to the increase in concentrations of both boric acid and glutathione. Combined applications were significantly superior than using each material alone in enhancing such two growth parameters. Application of glutathione significantly stimulated such two growth traits compared to using boric acid. The maximum values were recorded on the trees that received three sprays of boric acid plus glutathione each at $0.10 \%$ without significant differences with those sprayed by the same combination at $0.05 \%$.The untreated trees produced the lowest values. These results were true during both seasons.

\section{Leaf chemical components}

Data in Tables (2 and 3) clearly show that trees sprayed with boric acid and/or glutathione each at 0.025 up to $0.1 \%$ was significantly enhanced chlorophyll $a, b$, total chlorophylls and total carotenoids. Moreover, it was increased leaves mineral content i.e., (N, P, K, Mg, $\mathrm{Ca}$ and $\mathrm{S}$ ) as compared with control. There was a gradual promotion on leaf pigments and nutrients with increasing concentrations of both materials. Using glutathione was significantly superior to using boric acid in this respect. Combined applications were significantly effective on this respect than using each material alone. Three sprays of a mixture of boric acid and glutathione each at $0.1 \%$ were responsible for maximizing these plant pigments and nutrients without significant differences with those sprayed by the same combination at $0.05 \%$. The lowest values were recorded on the untreated trees. These results were true during 2014 and 2015 seasons. 


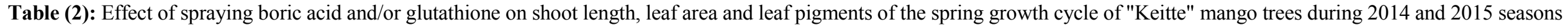

\begin{tabular}{|c|c|c|c|c|c|c|c|c|c|c|c|c|}
\hline \multirow[t]{2}{*}{ Treatment } & \multicolumn{2}{|c|}{$\begin{array}{l}\text { Shoot length } \\
(\mathrm{cm})\end{array}$} & \multicolumn{2}{|c|}{ Leaf area $(\mathrm{cm})^{2}$} & \multicolumn{2}{|c|}{$\begin{array}{l}\text { Chlorophyll a } \\
\text { (mg/100g F.W) }\end{array}$} & \multicolumn{2}{|c|}{$\begin{array}{c}\text { Chlorophyll b } \\
\text { (mg/100g F.W) }\end{array}$} & \multicolumn{2}{|c|}{$\begin{array}{c}\text { Total chlorophylls } \\
\text { (mg/100g F.W })\end{array}$} & \multicolumn{2}{|c|}{$\begin{array}{c}\text { Total carotenoids } \\
(\mathrm{mg} / 100 \mathrm{~g} \text { F.W })\end{array}$} \\
\hline & 2014 & 2015 & 2014 & 2015 & 2014 & 2015 & 2014 & 2015 & 2014 & 2015 & 2014 & 2015 \\
\hline Control (sprayed with water) & 38.5 & 39.9 & 69.1 & 70.3 & 1.41 & 1.41 & 0.41 & 0.44 & 1.82 & 1.85 & 0.39 & 0.36 \\
\hline Boric acid at $0.025 \%$ & 40.1 & 41.9 & 70.6 & 71.3 & 1.72 & 1.74 & 0.51 & 0.52 & 2.23 & 2.26 & 0.47 & 0.43 \\
\hline Boric acid at $0.05 \%$ & 41.9 & 45.0 & 71.9 & 72.5 & 2.09 & 2.29 & 0.61 & 0.60 & 2.60 & 2.89 & 0.55 & 0.50 \\
\hline Boric acid at $0.1 \%$ & 42.0 & 45.3 & 72.0 & 72.7 & 2.19 & 2.32 & 0.62 & 0.61 & 2.75 & 2.93 & 0.56 & 0.51 \\
\hline Glutathione at $0.025 \%$ & 43.9 & 46.5 & 73.9 & 74.0 & 2.40 & 2.67 & 0.71 & 0.70 & 3.11 & 3.37 & 0.64 & 0.57 \\
\hline Glutathione at $0.05 \%$ & 46.0 & 47.9 & 76.0 & 74.9 & 2.71 & 3.06 & 0.82 & 0.78 & 3.53 & 3.84 & 0.70 & 0.64 \\
\hline Glutathione at $0.1 \%$ & 46.3 & 48.0 & 76.7 & 75.0 & 2.81 & 3.12 & 0.83 & 0.79 & 3.64 & 3.91 & 0.71 & 0.66 \\
\hline Both at $0.025 \%$ & 48.0 & 49.2 & 79.0 & 76.0 & 3.19 & 3.57 & 0.90 & 0.89 & 4.09 & 4.46 & 0.80 & 0.75 \\
\hline Both at $0.05 \%$ & 50.6 & 50.5 & 80.3 & 78.9 & 3.40 & 3.73 & 0.97 & 0.96 & 4.37 & 4.71 & 0.87 & 0.82 \\
\hline Both at $0.1 \%$ & 51.0 & 50.6 & 80.7 & 79.0 & 3.51 & 3.83 & 0.98 & 0.97 & 4.49 & 4.80 & 0.88 & 0.83 \\
\hline New L.S.D at 5\% & 1.3 & 1.2 & 1.0 & 0.9 & 0.14 & 0.15 & 0.07 & 0.08 & 0.14 & 0.15 & 0.07 & 0.06 \\
\hline
\end{tabular}

Table (3): Effect of spraying boric acid and/or glutathione on leaves mineral content of "Keitte" mango trees during 2014 and 2015 seasons

\begin{tabular}{|c|c|c|c|c|c|c|c|c|c|c|c|c|}
\hline \multirow{2}{*}{ Treatment } & \multicolumn{2}{|c|}{ Leaf $N \%$} & \multicolumn{2}{|c|}{ Leaf $P \%$} & \multicolumn{2}{|c|}{ Leaf $\mathrm{K} \%$} & \multicolumn{2}{|c|}{ Leaf Mg \% } & \multicolumn{2}{|c|}{ Leaf Ca \% } & \multicolumn{2}{|c|}{ Leaf S \% } \\
\hline & 2014 & 2015 & 2014 & 2015 & 2014 & 2015 & 2014 & 2015 & 2014 & 2015 & 2014 & 2015 \\
\hline Control (trees sprayed with water) & 1.15 & 1.23 & 0.04 & 0.04 & 0.99 & 1.00 & 0.47 & 0.50 & 1.33 & 1.29 & 0.06 & 0.05 \\
\hline Boric acid at $0.025 \%$ & 1.23 & 1.29 & 0.07 & 0.08 & 1.05 & 1.06 & 0.51 & 0.53 & 1.44 & 1.40 & 0.10 & 0.09 \\
\hline Boric acid at $0.05 \%$ & 1.30 & 1.36 & 0.12 & 0.11 & 1.11 & 1.11 & 0.55 & 0.57 & 1.55 & 1.51 & 0.14 & 0.14 \\
\hline Boric acid at $0.1 \%$ & 1.31 & 1.37 & 0.13 & 0.12 & 1.12 & 1.12 & 0.56 & 0.58 & 1.57 & 1.52 & 0.15 & 0.15 \\
\hline Glutathione at $0.025 \%$ & 1.40 & 1.44 & 0.16 & 0.15 & 1.20 & 1.17 & 0.62 & 0.64 & 1.70 & 1.66 & 0.18 & 0.18 \\
\hline Glutathione at $0.05 \%$ & 1.49 & 1.50 & 0.20 & 0.18 & 1.29 & 1.23 & 0.69 & 0.67 & 1.80 & 1.77 & 0.21 & 0.22 \\
\hline Glutathione at $0.1 \%$ & 1.50 & 1.50 & 0.21 & 0.19 & 1.30 & 1.24 & 0.70 & 0.68 & 1.81 & 1.78 & 0.22 & 0.23 \\
\hline Both at $0.025 \%$ & 1.59 & 1.55 & 0.24 & 0.22 & 1.40 & 1.33 & 0.74 & 0.72 & 1.94 & 1.89 & 0.26 & 0.27 \\
\hline Both at $0.05 \%$ & 1.69 & 1.61 & 0.27 & 0.25 & 1.46 & 1.40 & 0.78 & 0.75 & 2.04 & 2.01 & 0.29 & 0.31 \\
\hline Both at $0.1 \%$ & 1.70 & 1.62 & 0.28 & 0.26 & 1.47 & 1.41 & 0.81 & 0.76 & 2.05 & 2.03 & 0.30 & 0.32 \\
\hline New L.S.D at 5\% & 0.06 & 0.05 & 0.03 & $\mathbf{0 . 0 3}$ & 0.04 & 0.04 & 0.03 & 0.03 & 0.09 & 0.10 & 0.03 & 0.03 \\
\hline
\end{tabular}




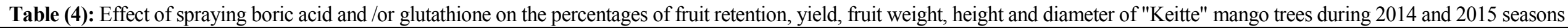

\begin{tabular}{|c|c|c|c|c|c|c|c|c|c|c|c|c|}
\hline \multirow{2}{*}{ Treatment } & \multicolumn{2}{|c|}{ Fruit retention \% } & \multicolumn{2}{|c|}{ No. of fruits/tree } & \multicolumn{2}{|c|}{ Yield/tree (kg.) } & \multicolumn{2}{|c|}{ Fruit weight (g.) } & \multicolumn{2}{|c|}{ Fruit height (cm) } & \multicolumn{2}{|c|}{ Fruit diameter $(\mathrm{cm})$} \\
\hline & 2014 & 2015 & 2014 & 2015 & 2014 & 2015 & 2014 & 2015 & 2014 & 2015 & 2014 & 2015 \\
\hline Control (trees sprayed with water) & 0.71 & 0.72 & 36.0 & 35.0 & 14.2 & 13.9 & 395.0 & 397.0 & 11.0 & 10.9 & 7.9 & 7.7 \\
\hline Boric acid at $0.025 \%$ & 0.78 & 0.81 & 38.0 & 38.0 & 15.2 & 15.3 & 401.0 & 403.0 & 11.3 & 11.2 & 8.1 & 7.9 \\
\hline Boric acid at $0.05 \%$ & 0.85 & 0.89 & 40.0 & 40.0 & 16.4 & 16.5 & 410.0 & 411.7 & 11.6 & 11.5 & 8.3 & 8.1 \\
\hline Boric acid at $0.1 \%$ & 0.86 & 0.90 & 41.0 & 40.0 & 16.9 & 16.5 & 411.0 & 412.0 & 11.7 & 11.6 & 8.3 & 8.1 \\
\hline Glutathione at $0.025 \%$ & 0.99 & 0.97 & 42.0 & 43.0 & 17.5 & 18.0 & 417.0 & 419.0 & 12.0 & 11.9 & 8.5 & 8.3 \\
\hline Glutathione at $0.05 \%$ & 1.01 & 1.05 & 44.0 & 45.0 & 18.6 & 19.1 & 422.0 & 425.0 & 12.2 & 12.1 & 8.7 & 8.5 \\
\hline Glutathione at $0.1 \%$ & 1.02 & 1.06 & 44.0 & 45.0 & 18.6 & 19.2 & 423.0 & 425.9 & 12.3 & 12.4 & 8.8 & 8.6 \\
\hline Both at $0.025 \%$ & 1.10 & 1.15 & 46.0 & 47.0 & 20.2 & 20.4 & 439.0 & 433.0 & 12.5 & 12.5 & 9.0 & 8.8 \\
\hline Both at $0.05 \%$ & 1.16 & 1.22 & 48.0 & 49.0 & 21.7 & 21.5 & 452.0 & 439.0 & 12.7 & 12.8 & 9.2 & 9.0 \\
\hline Both at $0.1 \%$ & 1.17 & 1.23 & 48.0 & 50.0 & 21.7 & 22.0 & 453.0 & 440.0 & 12.7 & 12.9 & 9.3 & 9.0 \\
\hline New L.S.D at 5\% & 0.06 & $\mathbf{0 . 0 7}$ & 2.0 & 2.0 & 0.7 & 0.8 & 5.0 & 5.1 & 0.2 & 0.2 & 0.2 & 0.2 \\
\hline
\end{tabular}

Table (5): Effect of spraying boric acid and/or glutathione on some physical and chemical fruit characteristics of "Keitte" mango trees during 2014 and 2015 seasons

\begin{tabular}{|c|c|c|c|c|c|c|c|c|c|c|c|c|}
\hline \multirow{2}{*}{ Treatment } & \multicolumn{2}{|c|}{$\begin{array}{c}\text { Fruit thickness } \\
(\mathrm{cm})\end{array}$} & \multicolumn{2}{|c|}{ Seed weight $\%$} & \multicolumn{2}{|c|}{ Peel thickness (mm) } & \multicolumn{2}{|c|}{ Pulp \% } & \multicolumn{2}{|c|}{$\begin{array}{c}\text { Edible/non-edible } \\
\text { portions of fruit }\end{array}$} & \multicolumn{2}{|c|}{ T.S.S.\% } \\
\hline & 2014 & 2015 & 2014 & 2015 & 2014 & 2015 & 2014 & 2015 & 2014 & 2015 & 2014 & 2015 \\
\hline Control (trees sprayed with water) & 7.0 & 6.7 & 10.0 & 10.5 & 14.0 & 13.9 & 76.0 & 75.6 & 3.2 & 3.1 & 9.0 & 9.3 \\
\hline Boric acid at $0.025 \%$ & 7.2 & 6.9 & 9.8 & 10.2 & 13.7 & 13.6 & 76.5 & 76.2 & 3.3 & 3.2 & 9.4 & 9.7 \\
\hline Boric acid at $0.05 \%$ & 7.5 & 7.2 & 9.5 & 10.0 & 13.4 & 13.2 & 77.1 & 76.8 & 3.4 & 3.3 & 9.7 & 10.0 \\
\hline Boric acid at $0.1 \%$ & 7.5 & 7.2 & 9.4 & 9.9 & 13.3 & 13.1 & 77.3 & 77.0 & 3.4 & 3.3 & 9.8 & 10.0 \\
\hline Glutathione at $0.025 \%$ & 7.7 & 7.5 & 9.3 & 9.4 & 13.0 & 12.8 & 77.7 & 77.2 & 3.5 & 3.4 & 10.2 & 10.4 \\
\hline Glutathione at $0.05 \%$ & 7.9 & 7.7 & 9.0 & 9.0 & 12.7 & 12.5 & 78.3 & 77.5 & 3.6 & 3.4 & 10.6 & 10.8 \\
\hline Glutathione at $0.1 \%$ & 8.0 & 7.8 & 9.0 & 8.9 & 12.6 & 12.4 & 78.4 & 78.7 & 3.6 & 3.7 & 10.7 & 10.9 \\
\hline Both at $0.025 \%$ & 8.2 & 8.0 & 8.8 & 8.7 & 12.2 & 12.0 & 79.0 & 79.3 & 3.8 & 3.8 & 11.1 & 11.3 \\
\hline Both at $0.05 \%$ & 8.5 & 8.2 & 8.5 & 8.5 & 12.0 & 11.8 & 79.5 & 79.7 & 3.9 & 3.9 & 11.5 & 11.6 \\
\hline Both at $0.1 \%$ & 8.5 & 8.2 & 8.4 & 8.5 & 11.9 & 11.8 & 79.7 & 79.7 & 3.9 & 3.9 & 11.6 & 11.7 \\
\hline New L.S.D at $5 \%$ & 0.2 & 0.2 & 0.2 & 0.2 & 0.3 & 0.3 & 0.4 & 0.4 & 0.2 & 0.2 & 0.3 & 0.3 \\
\hline
\end{tabular}


Table (6): Effect of spraying boric acid and/or glutathione on some fruit chemical characteristics of "Keitte" mango trees during 2014 and 2015 seasons

\begin{tabular}{|c|c|c|c|c|c|c|c|c|c|c|}
\hline \multirow{2}{*}{ Treatment } & \multicolumn{2}{|c|}{ Total acidity \% } & \multicolumn{2}{|c|}{ Total sugars $\%$} & \multicolumn{2}{|c|}{ Reducing sugars\% } & \multicolumn{2}{|c|}{$\begin{array}{l}\text { Vitamin } C \text { content } \\
\text { (mg/100 ml juice) }\end{array}$} & \multicolumn{2}{|c|}{ Total fibre $\%$} \\
\hline & 2014 & 2015 & 2014 & 2015 & 2014 & 2015 & 2014 & 2015 & 2014 & 2015 \\
\hline Control (trees sprayed with water) & 0.764 & 0.781 & 7.1 & 6.8 & 3.1 & 3.0 & 44.6 & 46.0 & 1.11 & 1.09 \\
\hline Boric acid at $0.025 \%$ & 0.744 & 0.761 & 7.3 & 7.1 & 3.3 & 3.2 & 45.7 & 47.3 & 1.03 & 1.00 \\
\hline Boric acid at $0.05 \%$ & 0.711 & 0.728 & 7.6 & 7.4 & 3.5 & 3.4 & 47.0 & 48.5 & 1.00 & 0.93 \\
\hline Boric acid at $0.1 \%$ & 0.709 & 0.725 & 7.7 & 7.5 & 3.6 & 3.5 & 47.3 & 48.7 & 0.91 & 0.92 \\
\hline Glutathione at $0.025 \%$ & 0.680 & 0.705 & 7.9 & 7.7 & 3.8 & 3.7 & 48.5 & 50.0 & 0.94 & 0.86 \\
\hline Glutathione at $0.05 \%$ & 0.661 & 0.671 & 8.1 & 7.9 & 4.0 & 4.0 & 44.6 & 51.3 & 0.88 & 0.80 \\
\hline Glutathione at $0.1 \%$ & 0.659 & 0.650 & 8.1 & 8.0 & 4.1 & 4.1 & 50.0 & 51.6 & 0.87 & 0.78 \\
\hline Both at $0.025 \%$ & 0.621 & 0.619 & 8.3 & 8.2 & 4.3 & 4.3 & 51.9 & 52.7 & 0.75 & 0.74 \\
\hline Both at $0.05 \%$ & 0.601 & 0.594 & 8.6 & 8.5 & 4.5 & 4.6 & 54.0 & 54.0 & 0.69 & 0.70 \\
\hline Both at $0.1 \%$ & 0.600 & 0.593 & 8.6 & 8.6 & 4.6 & 4.7 & 54.3 & 54.3 & 0.68 & 0.67 \\
\hline New L.S.D at 5\% & 0.015 & 0.014 & 0.2 & 0.2 & 0.2 & 0.2 & 0.9 & 1.0 & 0.02 & 0.02 \\
\hline
\end{tabular}




\section{Percentages of fruit retention and yield}

Data in Table (4) obviously reveal that fruit retention $\%$ as well as yield expressed as weight and number of fruits/tree were significantly improved in response to the tested treatments as compared to the control. Combined applications were superior than using each material alone in enhancing fruit retention and yield/tree. Among the combined treatments, the highest fruit retention (1.17 and $1.23 \%$ ), number of fruit per tree (48.0 and 50.0\%) and yield/ tree (21.7 and 22.0 $\mathrm{Kg}$ ) resulted from trees treated by combined treatment at $0.1 \%$, with increments over the control by $(64.7$ and $70.8 \%$ ) for fruit retention, (33.3 and 42.8) for number of fruit per tree and (52.8 and 58.2\%) for yield / tree in the first and second seasons, respectively, without significant differences with those treated by the same combined treatments but at $.05 \%$. Therefore, from the economical point of view, it is advised to use this treatment at $0.05 \%$ to obtain acceptable yield of "Keitte" mango trees grown under sandy calcareous soil. Under such promising treatment, yield per tree reached 21.7 and $21.5 \mathrm{~kg}$ while the untreated trees produced 14.2 and $13.9 \mathrm{~kg}$ during both seasons, respectively. The percentage of increment on the yield due to this application over the control reached 52.8 and $54.7 \%$ during both seasons, respectively. These results were true during both seasons.

\section{Fruit quality}

It is evident from the data in Tables (4 to 6) that subjecting "Keitte" mango trees three times to boric acid and/or glutathione each at 0.025 up to $0.1 \%$ significantly was responsible for improving quality of the fruits in terms of increasing weight, height, diameter and thickness of fruit, pulp $\%$, edible to non-edible portion of the fruit, T.S.S. $\%$, total and reducing sugars $\%$ and vitamin $\mathrm{C}$ content and decreasing percentages of seeds and peels, total acidity $\%$ and total fiber as compared to the control. Using glutathione was significantly favorable than using boric acid in enhancing fruit quality. Using boric acid combined with glutathione significantly surpassed the application of each solitary in enhancing fruit quality. Increasing concentrations of boric acid and glutathione from each at 0.05 to $0.1 \%$ failed significantly to show significant promotion on quality parameters. From economical point of view, it is suggested to sprays a mixture of boric acid and glutathione each at $0.05 \%$ for producing acceptable fruits with good quality. Untreated trees produced the lowest fruit quality. These results were true during both seasons.

\section{DISCUSSION}

The outstanding effect of glutathione on enhancing the biosynthesis of proteins, sugars, amino acids and sulphur compounds as well as stimulating cell division and preventing the release of reactive oxygen species (ROS) and protecting the plant cells from senescence could explain the present results. The positive action of glutathione on enhancing the tolerance of plants to all biotic and a biotic stresses especially drought conditions (Rennenberg, 1982;
Meister and Anderson, 1983; Jorge et al., 1993; Foyer and Lelandias, 1993; Szala et al., 2008) could result in enhancing growth and fruiting of fruit crops.

These results are in agreement with those obtained by Mahgoub-Mona et al. (2006), El-Khawaga et al. (2007), Mohamed (2012), Abdelaal et al. (2012), Gad El-Kareem (2012), Ahmed et al. (2012), ElKhawaga and Mansour (2014), and Gaber (2016).

The beneficial effects of boron on growth, tree nutritional status, fruit setting, yield and fruit quality of "Keitte" mango trees might be attributed to its positive function on stimulating the biosynthesis and translocation of sugars, cell division, root development, germination of pollen tubes, building of natural hormones as well as the uptake of most nutrient and water (Mengel et al., 2001).The beneficial effects of boron on preventing the dropping of flowers, formation of starch and the incidence of different disorders could add good explanation (Perica et al., 2001 and Marschner, 2012). The outstanding effect of boron on advancing fruit maturity was reported by (Ahmad et al., 2009).

These results are in agreement with those obtained by Abdalla (2005), Harhash and Abdel-Nasser (2010), Gamal (2013), Hassan-Huda (2014), Mohamed et al. (2015), Abd El-Wahab (2015), Mahmoud (2015), Abdelbaky (2015), Mahmoud (2016), and HabasyRanda et al. (2016).

\section{CONCLUSION}

For promoting yield and fruit quality of "Keitte" mango trees grown under sandy calcareous soil, it is advised to spray boric acid plus glutathione each at $0.05 \%$ three times at monthly intervals starting from the first week of March.

\section{REFERENCES}

Abdalla, A.A. (2008). Behaviour of Zaghloul date palms to some pollen carriers and boron. M. Sc. Thesis, Fac. of Agric., Mima Univ., Egypt.

Abd-Allah, A. S. E. (2006). Effect of spraying some macro and micro nutrients on fruit set, yield and fruit quality of Washington Navel orange trees. J. Agric. Appl. Sci. Res., 2(11): 10591063.

Abdelaal, A. M. K., A. A. B. Masoud and A. Y. Mohamed (2012). Response of Taimour mango trees to application of the antioxidant glutathione. Menufiya J. Agric. Res., 3: 303310.

Abdelbaky, O. A. A. (2015). Effect of some micronutrients and growth regulators spraying on fruiting of Zaghloul and Sewy date palm cvs. Ph. D. Thesis, Fac. of Agric., Al Azhar Univ., Assiut, Egypt.

Abd El-Wahab, H. A. M. (2015). Response of Succary mango trees to foliar application of silicon and boron. M.Sc. Thesis, Fac. of Agric., Minia Univ., Egypt. 
Abo El-Komsan, E. A., M. Y. Hegab and A. FouadAmera (2003). Response of Balady orange trees to application of some nutrients and citric acid. Egypt. J. Appl. Sci., 18(1): 228-246.

Ahmad, W., A. Niaz, S. Kanwal and A. Rahinatullah (2009). Role of Boron in Plant Growth: A review J. Agric. Res., 47(3): 329-338.

Ahmed, F. F. and M. H. Morsy (1999). A new method for measuring leaf area in different fruit species. Minia J. of Agric. Res. \& Develop., 19: 97-105.

Ahmed, F.F., M. M. Al-Wasfy and A. M. Madian (2012). Fruiting of Zaghloul date palms in response to foliar application of the antioxidant glutathione. Minia J. of Agric. Res \& Develop., 32(4): 1123-1140.

Al-Qubaie, A. I. (2012). Response of sunflower Giza 102 (Helianthus annus) plants to spraying some antioxidants. Minia J. of Agric., Res \& Develop., 32(2): 10-30.

A.O.A.C. (2000). Official Methods of Analysis (A.O.A.C), $16^{\text {th }}$ Ed., Benjamin Franklin Station, Washington D.C., U.S.A. pp.490-510.

Carter, M. R. (1993). Soil Sampling and Methods of Analysis. Canadian Soc. Soil Sci. Lewis Publishers, London, Tokyo, ISBN-10 0873718615.

Chapman, H. D. and P. P. Pratt (1965). Methods of Analysis for Soils, Plants and Water. Univ. of California. Division of Agric. Sci., 172-173.

De-Kok, I. J. and I. Stulen (1993). Role of glutathione in plants under oxidative stress. Sulfur nutrition and assimilation in higher plants. SPB Academic Publishing. Netherlands, pp. 125138.

Desouky, I. M., A. El- Hamady, A. Hassan and A. Abdel-Hamid (2007). Effect of spraying Barhee flowers with potassium sulphate and boric acid on fruit set, productivity and date properties. $4^{\text {th }}$ Symp. on Date Palm in Saudi Arabia (Challenges of Processing, Marketing and Pests Control). Date Palm Res. Center, King Faisal Univ., Al-Hassa 5-8 May, Abstracts Book, pp 76.

Ebeid-Sanaa (2007). The promotive effect of seaweed extract and boron on growth and fruiting of Hindy Bisinnara mango trees. Minia J. of Agric. Rev \& Develop., 27(3): 579-594.

El-Khawaga, A. S. and A. E. M. Mansour (2014). Promoting productivity of Washington Navel orange trees by using some crop seed sprout extracts, silicon and glutathione. Middle East Journal of Applied Sciences, 4(3): 779-785.

El-Khawaga, A. S., A. B. Abou-El-Khashab and M. A. El-Eraky (2007). Impact of water withholding before ripening, zinc and glutathione on fruit splitting and productivity of Manfalouty pomegranate trees. Minia. J. of Agric. Res. \& Develop., 27(3): 481-496.

El-Sayed-Esraa, M. H. (2007). Response of Ewaise mango trees to foliar application of boron. M. Sc. Thesis, Fac. of Agric., Minia Univ., Egypt.
Foyer, C. H. and S. Lelandias (1993). The role of ascorbate in regulation of photosynthesis. In Yamamato, Y.; Smith, C. 11.(Ed), photosymhetic responses to the environment.

Gaber, M. H. M. (2016). Response of Succary mango trees to foliar applications of glutathione and boric acid. M.Sc. Thesis, Fac. of Agric., Minia Univ. Egypt.

Gad El-Kareem, M. R. (2012). Improving productively of Taimour mango trees by using glutathione, silicon and vitamin B. Minia J. of agric. Res. \& Develop, 32(7): 1105-1121.

Gamal, A. F. O. (2013). Fruiting of Washington Navel orange trees in relation to application of seaweed extract, boron and citric acid. Ph. D. Thesis, Fac. of Agric., Minia Univ., Egypt.

Grill, D., T. Tausz and L. J. De-kok (2001). Significance of glutathione in plant adaptation to Verlage Germany, 10-20.

Habasy-Randa, E. Y., E. Helal-Mona, A. M. Abd ElRahman and F. F. Ahmed (2016). Effect of calcium and boron sources and methods of application on growth of Navel orange trees. Arab Univ. J. Agric. Sci., Ain Shams Univ., Cairo, 24(1): 185-193.

Harhash, M. M. and G. Abdel-Nasser (2010). Impact of spraying the date palm Khalas cv, bunches, with potassium and boron on fruit set, yield, fruit quality and nutrient content. Aust. J. Basic. Applied Sci., 4(9): 4164-4172.

Hassan-Huda, M. (2014). Impact of effective microorganisms and amino acids enriched with some nutrients on growth and fruiting of Valencia orange trees. Ph. D. Thesis, Fac. of Agric., Minia Univ., Egypt.

Ibrahim, H. I. M. and M. M. Al-Wasfy (2014). The promotive impact of using silicon and selenium with potassium and boron on fruiting of Valencia orange trees grown under Minia region conditions. World Rural Observations, 6(2):28-36.

Jorge, H. S., H. F. Leslie and J. H. H. C. Tony (1993). Glutathione content in peach buds in relation to development and release of Rest. Plant and cell Physiology, 33(7): 867-872.

Khattab, H. (2007). Role of glutathione and polyadenylic acid on the oxidative defense systems of two different cultivars of Canola Seedlings Grown under Saline Condition. Aust. J. of Basic and Appl. Sci., 1(3): 323-334.

Kocsy, G., G. A. Galiba and C. Brunoid (2001). Role of glutathione in adaptation and signaling during chilling and cold acclimation in plants. Physis. Plant., 113: 158-164.

Mahgoub-Mona, H., G. Abd El- Aziz-Nahed and A. A. Youssef (2006). Influence of foliar sprays with paclobutrazol or glutathione on growth, flowering and chemical composition of calendula officials 1-Plants J. of Applied Sci. Res., 2(11): 879-883.

Mahmoud, Kh, M. H. (2016). Response of Balady mandarin trees to foliar application of boron 
and silicon. Ph. D. Thesis, Fac. of Agric., Minia Univ., Egypt.

Marschner, P. (2012). Mineral Nutrition of Higher Plants .Marschner (Ed.) Academic press. Third edition. Mineral Nutrition. Yield and SourceSink Relationships, pp.115-116 Elsevier.

Mahmoud, S. E. A. (2015). Fruiting of Ewaise mango trees in relation to spraying royal jelly, magnesium and boron. M. Sc. Thesis, Fac. of Agric., Minia Univ., Egypt.

Meister, A and M. E. Anderson (1983). Glutathione. Annual Rev. of Biochemistry, 52: 711-760.

Mengel, K. E., E. A. Kirkby, H. Kosegarten and T. Appel (2011). Principles of Plant Nutrition $5^{\text {th }}$ ed. Kluwer Academic publishers Dordecht, p. 1-311.

Mohamed, M. A. A., M. A. El-Sayed and H. A. M. Abd El-Wahab (2015). Response of Succary mango trees to foliar application of silicon and boron. World Rural observation, 7(2): 93-98.

Mohamed, N. E. M. (2012). Effect of glutathione on yield and yield components of sunflower cv. Giza 102 under Souhag conditions. Minia J. of Agric. Res. \& Develop., 32(7): 1005:1018.

Mostafa, R. A. A. (2015). Effect of zinc, boron and active dry yeast sprays on yield and fruit quality of Zaghloul date palm. Arab Univ. J. Agric. Sci., Ain Shams Univ., Cairo, 23(2): 467-473.

Mulleineaux, P. M. and T. Rausch (2005). Glutathione, photosynthesis and redox regulation stress response gen expression photosynthesis Res., 47: 459-474.

Noctor, G. and C. H. Foyer (1998). Ascorbate and glutathione: keeping active oxygen under control. Ann. Rev of Plant Physiol. and Plant Mol. Biol., 49: 249-279.

Peacock, W. L. and L. P. Christensen (2005). Drip irrigation can effectively apply boron to San Joaquin Valley vineyards. Calif. Agric., 59:188-191.

Perica, S., N. Bellaloui, C. Greve, P. H. Hu H. and P. H. Brown (2001). Boron transport and soluble carbohydrate concentrations in olive. J. Amer. Soc. Hort. Sci., 126: 291-296.

Rennenberg, H. (1982). Glutathione metabolism and possible biological roles in higher plants. Phytochemistry, 21-2771-2781.

Snedecor, G. A. V. and G. W. Cochran (1989). Statistical Methods. $7^{\text {th }}$ ed. Iowa State Univ. Press. Ames, Iowa, U.S.A 507.

Summer, (1985). Diagnosis and Recommendation Integrated system (DKIS) as a guide to orchard fertilization Hon. Abst., 55(8): 7502.

Szala, G. T., G. Galibo and G. Koscy (2008). Glutathione as an antioxidant and regulatory molecule in plants under abiotic stress conditions. J. of Plant Growth Regulation. Springer Sci., BV. Sinus Media.

Von-Wettstein, D. Y. (1957). Clatale und der Submikro Skopisne Formwechsel de plastids. Experimental Cel Research, 12: 427.

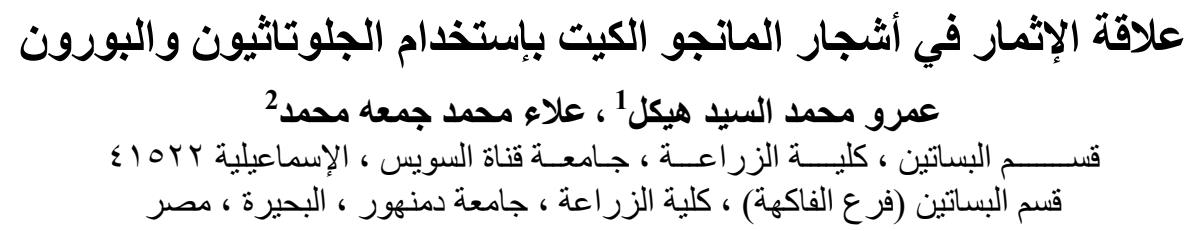

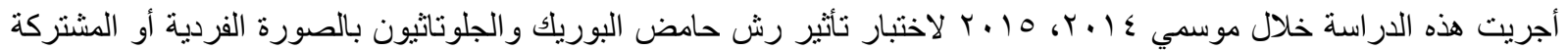

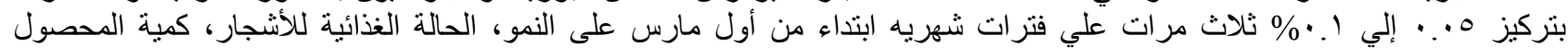

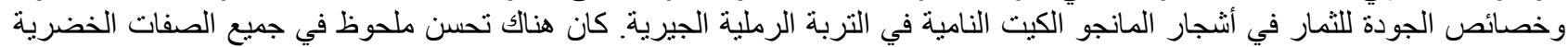

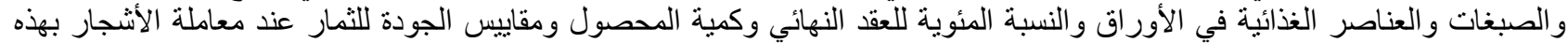

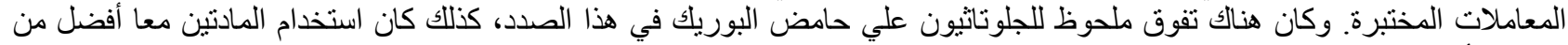

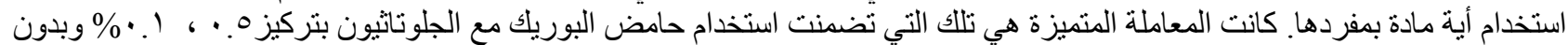

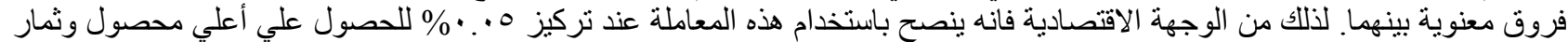

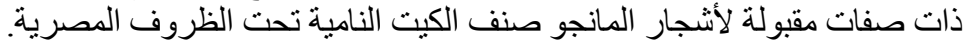

الكلمات الدالة: أثجار المانجو الكيت ، حمض البوريك ، الجلوتاثيون ، عدد مرات الرش ، كمية المحصول ، خصائص الجودة للثمار 